\title{
Dropout prevention in secondary VET from different learning spaces. A social discussion experience.
}

\author{
Francesca Salvà ${ }^{\star}$ Carme Pinya, Nuria Álvarez, Aina Calvo \\ University of the Balearic Islands Department of Applied Pedagogy and Educational Psycholo- \\ gy Edifici Guillem Cifre de Colonya. Campus de la UIB. Cra de Valldemossa s/n 07122 Palma
}

Received: 21.05.2018; Accepted: 17.04.2019; Published: 29.08.2019

\begin{abstract}
Context: In 2016, the early leaving from education and training (ELET) rate in the Balearic Islands, Spain, was $26.8 \%$. According to the most recent data, the participation rate in intermediate vocational education and training (VET) was $31.5 \%$, and the graduation rate was $53.2 \%$. In this paper, we present the main elements of the social agreement among political and social actors, derived from social discussion, which may form the main building blocks for addressing the problems of ELET and, more specifically, dropout in VET.

Approach: The social discussion was developed under the need for a broader and more inclusive vision between the formal education system and the community as well as among their agents and initiatives, the mutual understanding between the educational strategies and the models of formal and non-formal education systems and the need for a dynamic and holistic approach to experiential learning processes. As researchers, we analysed the videorecorded content of participants' contributions using three categories: problems, strategies for improvements and contributions of the work group to the social agreement.

Findings: The experience evidenced the severity of the ELET problem in the Balearic Islands and proved that preventing ELET and returning people between the ages of 16 and 24 to education and training programmes must become political priorities. The social agreement reflects the consensus reached regarding the need to work in networks, encourage collaboration between formal and non-formal education and emphasise the central role of the *Corresponding author: f.salva@uib.es
\end{abstract}


community and the active participation of students. The proposed actions regarding VET focus on the need to establish a system that integrates VET from education and from employment systems and the need to increase the offer to connect with the needs of businesses, the territory and a new model of production. The necessity of improving the quality of the system, moving towards more inclusive education and training teachers to recognize and reduce dropout risk factors was also brought up.

Conclusion: The social agreement is possible even in contexts with little tradition. The innovation of this experience lies in its equating all participants at the same level of discussion. We highlight the intersection of the variety of positions that emerged in the debates as well as the consensus reached regarding the suggested proposals to address the problem of ELET and dropout in VET in the Balearic Islands.

Keywords: Early leaving from education and training (ELET), Dropout, Vocational Education and Training,, Community and Experiential Learning, VET

\section{Introduction}

This paper presents a social discussion on early leaving from education and training (ELET) and specifically dropout in secondary vocational education and training (VET). It is the result of a collective action between the European Anti-Poverty Network of the Balearic Islands; the Cooperativa Jovent, a non-governmental organization (NGO) focused on labour-market and social integration of young people; and the 'Education and Citizenship' research group at the University of the Balearic Islands (UIB), which studies pathways leading to success and dropout among young people in VET programmes in Spain. This experience is part of a wider and longer collaboration developed as an action research process, guided by the in common interest in the emancipation of individuals and groups against injustice, irrationality, suffering, etc. (Carr \& Kemmis, 1986).

The need for a broader and more inclusive vision between the formal education system and the community as well as among their agents and initiatives; the deepening of mutual understanding between the educational strategies and the models of formal and non-formal education systems; and the need for a dynamic and holistic approach to experiential learning processes, led us to arrange the shared reflection activity we present herein.

This paper is broken down into eight sections, including the introduction. In section two, ELET, and specifically dropout from secondary VET in the Balearic Islands, is explained. Then, the Social Inclusion Pact, led by the European Anti-Poverty Network of the Balearic Islands, is presented. In the subsequent section, the role of third-sector organizations is analysed followed, in the fifth section, by a description of the characteristics of experiential learning as a learning theory of reference in the context of new learning networks for dropout 
prevention. The sixth section describes the research question and the methodology that we carried out, and the seventh section addresses the results that respond to the research question. The last section includes a discussion and conclusions regarding the social reflection experience.

\section{The Context: ELET and Dropout in Secondary VET in the Balearic Islands}

In 2016, 26.8\% of young people between the ages of 18 and 24 left the Balearic education system before obtaining a high school diploma (Advanced Secondary Education Qualification or intermediate VET) and without transferring to another school. According to this data, the Balearic ELET rate is well above Spanish (19\%) and European (10.7\%) averages (Ministry of Education, Culture and Sport, 2017).

In other studies, we have analysed the evolution of ELET rates in the Balearic Islands, highlighting current, deep-seated problems and the pessimistic outlook for social and educational policies if no major changes are made (Salvà Mut, 2017). We have also delved into the reasons behind dropout before earning the Compulsory Secondary Education Qualification (GESO). Literature on the subject suggests that the causes behind dropout are multidimensional, but in the case of the Balearic Islands, they are determined by the interrelationship between the characteristics of the labour market, poor academic results, and dominant social values (Salvà-Mut, Oliver-Trobat \& Comas-Forgas, 2014).

Low levels of participation and numerous dropouts from secondary VET (at the basic and intermediate levels) in Spain and the Balearic Islands lead to the high ELET rate. According to the European Centre for the Development of Vocational Training (Cedefop, 2016), higher levels of participation and higher graduation rates would have a positive effect on reducing this ELET rate.

Our longitudinal study tracked the pathways of a representative sample of students who began basic VET and intermediate VET in the Balearic Islands during the 2015/16 academic year, and the data obtained reflect high dropout rates. Given that both basic and intermediate VET programmes have a duration of two academic years, the data we gathered is partial and only reveals the number of dropouts that took place during or at the end of the first year of studies. Current data do not contain information concerning students who leave after the second year of studies nor the number of students who repeat a year. Despite this, the information provided by participating centres shows that $31.9 \%$ of the students who started a basic VET programme and $30.4 \%$ who began an intermediate VET programme, dropped out during or at the end of the first year (Salvà-Mut, 2018). An analysis, based on official statistics published by the Spanish government, of the participation and graduation rates in intermediate VET programmes show a nationwide participation rate of $38.7 \%$ (31.5\% in the 
Balearic Islands) and a graduation rate of 50.5\% (53.2\% in the Balearic Islands) (Salvà-Mut, Oliver-Trobat, Ruiz-Pérez, Psifidou, under review).

\section{The Social Inclusion Pact driven by EAPN}

On 14 October 2014, all political parties with parliamentary representation in the Balearic Islands signed the Social Inclusion Pact, which aims to improve the conditions of people at risk of falling into poverty or/and social exclusion and to facilitate and strengthen the activities of social entities that work with these groups.

The Pact was spearheaded by the European Anti-Poverty Network of the Balearic Islands (EAPN-IB). As explained on its website (https://www.eapn.eu), the EAPN is a network of 31 groups of national volunteer organizations and grassroots groups along with 13 European organizations involved in a variety of activities aimed at combating poverty and social exclusion, including, education and training activities, service provision and activities aimed at fomenting the participation and empowerment of people living in poverty and experiencing social exclusion. The EAPN aims to move the fight against poverty up on the EU's agenda and ensure cooperation at the EU level when it comes to eradicating poverty and social exclusion. The network has consultative status with the Council of Europe and is a founding member of the Social Platform (Platform of European Social NGOs).

As a result of the Social Inclusion Pact, all of the parliamentary groups, together with the EAPN-IB, have committed to introducing different measures across the public administrations of the Balearic Islands. These measures basically include the following: social inclusion measures designed for people living at risk of poverty and/or social exclusion and measures aimed at facilitating the relationships between social organizations that work with these groups and public administrations.

In order to ensure the implementation of these measures, a follow-up committee formed by representatives from Parliament and the EAPN-IB was created. It holds meetings periodically.

The committee decided to organize a two-day seminar to reflect upon and debate the issue of ELET in the Balearic Islands and also to involve our research group in the whole process, as we are the only one in Spain that coordinates an R\&D project focused on the pathways that lead to success in or dropout from VET (www.itinerariosfp.org). Specifically, we aim to provide scientific evidence, strategies and intervention instruments to further the knowledge about VET in secondary education (basic VET and intermediate VET) and, in particular, to help to reduce and correct the serious ELET problem.

The team involved in the project is led by the 'Education and Citizenship' research group (http://eic.uib.eu) at the UIB, and it includes researchers from various departments at the UIB, the Autonomous University of Barcelona and the University of Valencia. At the inter- 
national level, it is important to highlight the participation of the Swiss Federal Institute for Vocational Education and Training.

The establishment of strategic alliances is essential to the fight against educational exclusion and dropout, and these alliances must not only exist among the school, family and community but also among academic researchers, like the ones described in this article. The key point is to move from students having to make an effort to adapt to having the educational system adapt to the individual and collective needs of its youth (UNICEF, 2017). This idea will come up again in the following sections.

\section{$4 \quad$ New Learning Networks for Dropout Prevention: The Role of Third-Sector Organizations}

The educational landscape of the contemporary world is shifting from traditional educational institutions to open, diverse, complex learning spaces. We now find educational settings where professionals with different profiles (social educators, sociologists, anthropologists, social workers, etc.) carry out their work in collaborative partnerships with the educational community (teachers, students and families). This collaborative work, inside and outside of schools, is based on the concept that learning is a continuum in which formal educational institutions interact with non-formal educational experiences. 'The changes in the spaces, times and relations in which learning takes place favour a network of learning spaces where non-formal and informal spaces of learning will interact with and complement formal educational institutions.' UNESCO (2015, p. 48). In Spain, more and more secondary schools are carrying out service-learning programmes: educational projects that combine learning processes with activities that are of service to the community. With these programmes, participants learn to work around the real needs of their surroundings in order to improve them (Puig, Batlle, Bosch \& Palos, 2007, p. 20).

Furthermore, in Spain, third-sector organizations are responsible for the management of many of the education programmes in second chance schools. These programmes are mostly attended by young people who have not obtained their Compulsory Secondary Education Qualification and have been transferred to social services and/or school guidance services. Some of these young people have also been excluded from other school programmes, such as basic VET or Adult Secondary Education.

In 2015, a study conducted by the NGO Platform for Social Action (Plataforma de ONGs de Acción Social, 2015) to identify the impact of the crisis in the third sector of social action, emphasized the positive contribution of NGOs to Spanish society. Their reasoning included the following: its mobilizing role, the values they defend and promote and the fact that they respond to social needs. Furthermore, we should not forget the role that they play in economic development and the creation of employment as a part of the productive system. In fact, 
as noted in the study, even though the economic crisis decreased revenues, expenditures and employment in the social sector, its relevance in the Spanish economy has increased. Therefore, not only is the social work that these entities carry out important, but so is their role in the productive economy.

There is a broad consensus on the need to improve the quality of the existing educational supply, adjusting it to the characteristics and needs of its recipients and territories. With respect to this improvement, experts highlight the existing commitment of the professionals and institutions concerned (Salva-Mut, Oliver-Trobat \& Calvo-Sastre, 2006). NGOs involved with social action 'carry out integrated actions, to develop personal pathways of insertion, linking training and employment, and to permanently renew the programme for a better adaptation to the youth and labour market reality' (Lopez-Aranguren, 2004, p. 51). The professionals claim that 'there is no student who does not want to learn, what can happen, is that a student does not want to study the way the system has established' (EAPN, 2015, p. 34), and at the same time they defend that the right to education is not only acquiring a place in a school, but importantly, is the right to enrol in an educational programme focused on success. In working with young people, these entities promote a sense of belonging, which is 'fundamental to be socially inserted and to exercise citizenship, based on positive experiences of acceptance and participation, and the generation of future expectations' (LopezAranguren, 2007, p. 26).

Focusing on dropout prevention, there is strong evidence stressing that joint action from formal and non-formal education, especially from the community, is required. One of the leaders of the Tomillo Foundation (https://tomillo.org/en/), a Spanish organization dedicated to improving society by helping people in difficult situations better their lives and their community, points out:

Schools must abandon their traditional breeding, and open up to the rest of society assuming the role of extending educational opportunities and of facilitating local education networks. Similarly, any person or institution that can bring something for the benefit and growth of others should have the opportunity and the tools to do so through these local education networks. And anyone who wishes to learn, renew themselves professionally etc., throughout their lives, must have the opportunity to do so. This network organization must promote a rich and effective offer that includes the three useful learning categories: formal learning, nonformal and informal. (Lopez-Aranguren, 2007, p. 36)

\section{Experiential Learning and the Value of the Community}

Experiential learning (Kolb, 1984; Kolb \& Kolb, 2005 and 2017) is a significant conceptual framework for both formal and non-formal education programmes aimed at preventing dropout, especially those based on a deeper connection with the students' context of learning 
and with the future they begin to glimpse. As Taylor (2010) recommends, working on the partnerships between training centres and companies to make effective policies can increase the employability of young people instead of ignoring their needs in labour apprentices. In this sense, the contributions of the work of Moshuus (2018) remind us of the importance of prioritizing young people's perspective and raise the need for a more active involvement of the companies in such debates.

Experiential learning is developed in a continuum that unfolds in four steps: firstly, students begin the learning process from a specific action, experience or situation. From here, they observe the effects of their own actions and try to understand them. The third step in the process involves generalization and understanding the principles underlying the situation experienced, without that necessarily meaning the transformation of this knowledge into theoretical constructions. And, finally, the fourth step is the application of the acquired knowledge to new circumstances through action and following the generalization principle mentioned above.

Community resources (NGOs, community networks, etc.) are essential when connecting the learning experience of young people with the reality of their surroundings and their possible future learning paths (Institute of Education Sciences, 2017). The need for a greater permeability of educational institutions in promoting experiential learning is directly linked to the principles for designing learning environments formulated by the Organisation for Economic Co-operation and Development (OECD, 2017, p. 26), especially with respect to the seventh principle: 'the learning environment strongly promotes 'horizontal connectedness' across areas of knowledge and subjects as well as to the community and the wider world?. This powerful statement supports the idea that making connections, and especially empowering learners to be able to make these connections by themselves, promotes learning on a deeper level. In this sense, learners can integrate isolated objects of learning into larger frameworks of knowledge and curricular issues. In the words of Avis (2018, p. 22) 'expansive version of VET that embraces notions of citizenship, democracy and individual development are conditional upon the balance of power between labour and capital present within the social formation, and indeed beyond'.

Following the cycle of experiential learning, connections need to link the learning that takes place within and outside schools, and they need to be made in inter-disciplinary ways, as real-life problems are not governed by subjects. Thus, the group of educational agents expands and includes not only teachers but also other professionals (from the labour, social and community fields, etc.), families, the community and the wider world, and it becomes a powerful mechanism that offers learning possibilities to young people. Partnerships and networks become strategic tools for the design of teaching models and educational practices inside and outside classrooms. The successful experiences of second chance education, collected for more than one decade, by the Commission of the European Communities (2004, 
p. 11) confirm that 'innovative pedagogical approaches will be needed, as well as specialised guidance facilities, links with local enterprises and other measures designed to create a motivating learning environment within which second chance education can develop its full potential. The idea is to provide a social response to a social problem, as complex social problems require specific responses (Lopez-Aranguren, 2007, p. 44). The relationship between education and society becomes strategic in this policy change towards social justice (Walker \& Unterhalter, 2007).

\section{Social Discussion on ELET and Dropout in VET: Research Question and Methodology}

The research question pertaining to the experience described in this article is as follows: Deriving from social discussion, what are the points of social agreement between political and social actors, that might serve as the main building blocks from which to address the problem of ELET and, more specifically, of dropout in Secondary VET of young people?

It should be noted that the social agreement that was reached was the consequence of a two-day seminar that took place on the 8 and 9 of February 2018 at the house of the Parliament of the Balearic Islands, with a total of 95 participants on the first day and 35 on the second. The participant profile was diverse and included professionals from the VET field, professional community and social education workers, public administration technicians, and lastly, deputies from the Parliament of the Balearic Islands. Without any doubt, the most innovative and differentiating aspect of this social discussion was the participation of deputies from every one of the Parliament's political groups. This circumstance is even more extraordinary if we take into account that Spain does not have any tradition of having political educational pacts. In fact, quite the opposite is true. Since 1970, Spain has had seven education laws and none has enjoyed the political stability needed to meet the educational challenges that have come up.

Research on deliberative democracy shows that the support of (local) politicians for a deliberative procedure ('event-limited support') seems to enhance the probability of its success (Geisel \& Hess, 2017, p. 5). Additionally, empowered deliberation can increase 'the sense of political efficacy of both participants and observers and encourage them to value reasoned exchange of views and participation in the future' (Johnson \& Gastil, 2015, p. 6). Ours is an experience of egalitarian democracy as 'a new way of dealing with inequalities from a global and transformative point of view' (Subirats, 2012, 162).

We created the necessary conditions for an environment that was able to promote a relaxed dialogue. The most praiseworthy aspect of the social discussion was that the participants worked in the Parliament with a willingness to listen, discuss, compare and share. This intention went beyond the rapprochement of positions: during the social discussion, great 
effort was made to focus on converging rather than just adding. Following Nielsen, Bryndum and Bedsted $(2017$, p. 8 ) in creating the framing conditions for stakeholder workshops, we considered both 'the aims of stakeholder dialogue and the importance of participation contributing to existing representative processes. From our research perspective, one of the strategic actions to deal with the problem of ELET in the Balearic Islands, particularly of VET dropout, is to deepen the diversity of positions from the Sociology of Knowledge perspective (Keller, 2005, Zenner, 2017).

Each day of the seminar had a different level of social discussion. The first day, open to people interested in the subject upon registration, was structured around various presentations and round tables that dealt with diverse issues from international, national, regional and local perspectives. The second day consisted of a group work session led by a professional and addressed to specific invitees with a focus on both problems and solutions. The social discussion through group work was carried out via two types of dynamics (Cembranos \& Medina, 2003): (1) the 'wheel technique', which has the advantage of allowing everyone's opinion to be heard and of making all group members active participants, and (2) the 'past tomorrow method, which through creative thinking enables different work groups to design and describe an aspect of reality as they would like it to be in the medium- or long-term future, without taking immediate difficulties into consideration.

To respond to the posed research question, we analysed the video-recorded contents of the contributions made by the participants of the two-day seminar. These analyses were broken down into three categories: problems, strategies for improvements and measures for the future. The first two correspond to the main issues being considered by the presentations and the debate that took place during the first session. The third category was mostly based on the contributions made by the work groups that were formed during the second session and which focused on social agreement among the various actors involved.

\section{$7 \quad$ Results}

The results of the present work are presented in three different analytical categories: (1) problems; (2) strategies for combating ELET and specifically dropout from VET; and (3) contributions of the work group to the social agreement. The results are based on the contributions of the three types of participants in the social discussion: researchers; professionals, such as educational organizations and teachers; and political and technical managers, such as authorities in the public administration. 


\subsection{Problems}

The analyses are based on the results obtained by the 'Education and Citizenship' research group at the UIB in relation to the issue of ELET in VET and, more specifically, the evidence extracted from the project entitled 'Pathways leading to success in, or dropout from, vocational training in the education system at levels 1 and 2' (Ref EDU2013-42854-R). The main contributions of this presentation are described below.

An analysis of the ELET problem in the Balearic Islands highlights the severity and continuous nature of the issue, as well as the consistency between statistics related to academic results and the educational level in the Balearic Islands, namely:

- The ELET rate in 2016 was 26.8\%, while the Spanish rate was 19\% and the European rate was 10.7\% (Ministry of Education, Culture and Sport, 2017). In absolute terms this means that 20,990 young people aged 18 to 24 in the Balearic Islands were in this situation.

- The school failure rate (number of young people who did not obtain the Compulsory Secondary Education Qualification) was 31\%, while the Spanish average was 22.4\%, according to data from the 2014-15 academic year (Salvà-Mut, 2017).

- $40.6 \%$ of the population between 25 and 34, and $40.7 \%$ between 35 and 44 have a low level of education. This percentage was never less than $40 \%$ for any of the age groups, but the EU and OECD averages (2015 data) were $21 \%$ and $24 \%$, respectively (SalvàMut, 2017).

It is also important to highlight the uneven impact of sex, place of birth and social origin. A comparative population study of individuals between 26 and 28 years of age with low levels of education and others at the same age with higher levels of education in the municipality of Palma (Salvà-Mut, Thomas-Vanrell \& Quintana-Murci, 2016), exhibited trends similar to those described in international and Spanish literature on the topic, but to a greater degree: men $(60 \%$ vs. $45.6 \%)$, people born abroad $(20.5 \%$ vs. $14.3 \%)$ and those whose mother had only primary level studies ( $46.5 \%$ vs. $34.9 \%$ ).

As in a previous study (Salva-Mut, Oliver-Trobat \& Comas-Forgas, 2014), an analysis of the causes brought to light their multidimensional nature and how they progress, versus the one-dimensional vision that centres, almost exclusively, on the Balearic labour market effect (pull factors). In this context, the reflection focused on the factors that provoke school leaving (push factors), referring to the fact that, for many young people, it does not make sense to continue school, mainly because they do not feel comfortable, they do not feel capable of obtaining good academic results or they think that what they are studying has no future uti- 
lity. In addition, all of these elements occur during a specific moment of personal evolution characterized by the need for self-assertion in the context of a society where having money and consuming are dominant values.

The studies that we conducted in the Balearic Islands, based on the life stories of young people who have left school without obtaining the Compulsory Secondary Education Qualification, clearly show that finding work is related to bad academic results, but that students leaving school, do not always leave in order to work. They often seek other training styles in which they can succeed, and they also often find barriers when it comes to accessing them or persevering, due to the characteristics of the training being offered (Salvà-Mut, QuintanaMurci \& Desmarais, 2015).

The current 'post crisis' context has increased inequalities as well as the number of people who do not have the basic rights of citizenship. This was brought about by the effects of the economic crisis that started in 2008. The evidence is conclusive:

- Between 2009 and 2015, the number of people at risk of poverty in the Balearic Islands increased by 42,000 (Llano, 2017).

- The Balearic Islands is the Spanish autonomous community with the third highest rate of extreme poverty, affecting $10.4 \%$ of the population (Llano, 2017).

- Children under 18 years of age at risk of poverty or exclusion represent $34.1 \%$ of the total population of this age group in the Balearic Islands (2015), similar to the Spanish average. In absolute terms, it affects 69,178 minors (Unicef- Balearic Islands Committee, 2017).

Another central element worthy of consideration involves the main economic activity of the islands: tourism. The new movement towards mass tourism, with a model that increases the number of visitors in a disproportionate manner without considering the environmental and social limits of the territory, is occurring at the same time as labour conditions are worsening by successive labour reforms, which are implemented under the pretext of the crisis. Realestate speculation and low wages have led to an increase in the number of people who do not have access to housing, which has become a major social problem.

In this context, we consider the right to an intermediate level of education to be a right of citizens and a requirement for the population to actively exercise their citizenship in a 21stcentury society. We furthermore defend that, in the current situation, the development of appropriate upper-secondary education and training is essential for this right to be exercised, especially among the least favoured members or society. 


\subsection{Strategies for combating ELET and specifically dropout from VET}

Throughout the discussion, it was clear that preventing ELET and returning young people between the ages of 16 and 24 to education and training programmes had to become a priority in the political agenda of the Balearic Islands. When it was time to come up with strategies to address this problem, participants in the social discussion focused mainly on evidence from research, public policies and pedagogical practices.

Researchers participating in the discussion stressed the importance of promoting participation in and preventing dropout from VET programmes, as well as the need to come up with a strategic plan (in the short, medium and long terms) that includes a budget, evidencebased policies and strategies that can be evaluated and pilot plans at a territorial level with the participation of various actors and institutions

Three kinds of measures were also suggested, in accordance with the contributions of the Cedefop (2016): (a) preventive measures to avoid the conditions that trigger dropout processes (VET reforms, bridge programmes and VET preparatory courses; financial incentives to reduce VET dropout; specific prevention resources; and teacher and job tutor training); (b) intervention measures to address issues at an early stage (early warning systems for situations that may lead to dropout; professional support, including guidance and accompaniment; and time-out or short-term breaks); and (c) compensation or remedial measures aimed at offering training opportunities to those who have dropped out (open VET to new groups of students; VET second-chance programmes; second opportunity education programmes with the global perspective used by VET procedures).

During the discussion, it was generally agreed upon that the most common strategies involve reward or remediation within the basic VET programmes-as a part of the education system; projects, designed and managed by third sector players, that are specifically directed at young people - this under the framework of employment, due to increased flexibility when compared to the education system; and other projects and programmes under the framework of the Youth Guarantee Programme. It is for this reason that highlighting prevention and intervention strategies was a priority of the social discussion.

An example of good practices for basic VET programmes was given by a public secondary school (Sa Colomina, Ibiza). Teachers from this school explained the principles and relevant strategies that led to student perseverance and the completion of studies in basic VET. They presented two initiatives: the simulation of a company project made by students via video, and the tutoring action plan made by the educational team with another video. Both began three years ago with students in their first year of basic VET (electrical and electronic systems and computer components) and in two general modules (communication and society and applied sciences), with very positive results in terms of perseverance and completion of studies. 
Teachers underlined the contribution of learning from projects to the development of the following core competencies: linguistics, mathematics, knowledge and interaction with the physical world, information handling, digital and social citizenship, culture and fine arts, learning to learn, autonomy and personal initiative.

The representative third-sector project designed for young people was the 'Labour insertion, training, and guidance pathways' project from the Cooperativa Jovent. It is considered to be a flagship project in this field in the Balearic Islands and focuses on young people aged 16 to 29 who have left the formal education system. Since 1989 this second chance school has promoted various initiatives focusing on personal and vocational guidance and training as well as support in finding a job. Its pathways offer a wide and varied range of personal and professional orientation and training, as well as accompanying students through inclusion processes.

In both cases (Sa Colomina and Cooperativa Jovent) they welcomed students who had not yet obtained their Compulsory Secondary Education Qualification (ISCED 0-1) and both showed high levels of educational success. They utilized educational practices that were focused on preventing dropout, incorporating strategies that had shown themselves to be effective with the population groups that they were targeting (main tutor; actively searching for companies and modules focusing on professional practice and digital transformation; learning from projects), which allowed for early, individualized interventions (accompanying students and providing follow-up throughout the process; offering flexible and individual work plans; providing specific services for youth and families and participating in research with the UIB).

The Youth Guarantee Programme, aimed at young people under 30 who do not work or study, offers youth enrolled in this programme training, guidance and an internship or an employment contract in four months. In this context, the SOIB created and financed several training structures like the Young SOIB mixed programme offering training and employment with a duration of between 6 and 10 months carried out in collaboration with local authorities and other public entities. The training programme is part of the Professionalism Certificates (certifications that rely on the Public Employment Administration), which enable participants to accumulate professional modules that facilitate a progressive learning pathway to university. Specific orientation services have been also established within the framework of the Youth Guarantee Programme that perform the task coaching, which includes individualized follow-up through graduation and finding employment. The programme also provides people who return to Compulsory Secondary Education or VET studies with grants.

Under the framework of public policies that address preventing VET dropout, it is worth highlighting the promotion of dual VET programmes and the reinforcement of career counselling. Dual VET programmes are carried out in the same education system as other VET programmes, and they involve a one-year contract. The SOIB also conducts a dual VET pro- 
gramme with public, private and third-sector entities, and it finances a specific procedure for vulnerable youth, which includes a comprehensive tutoring process.

Regarding counselling, representatives from the public administration underlined the Academic and Professional Orientation Centres (POAP) - a collaboration between the autonomous government and the Employment Office of the Balearic Islands (SOIB). Considering the traditional academic counselling that is offered in secondary education centres and given the complexity of the VET system, the POAP carries out academic and career counselling focused on VET studies, taking into account the wide range of pathways offered and the permeability that exists between general and labour-related education and between the VET offered by the education system and the employment system (as well as recognition of previous work experience).

\subsection{Contributions of the work group: The social agreement}

In relation to the contributions of the work group, of note is the unanimous consensus that the problem being addressed is severe. The fact is that $30 \%$ of students leave their studies before their second year in secondary VET. This is an alarming figure in any case, and even more considering that it is post-compulsory education. The reasons for leaving include a lack of orientation and motivation, job offers before the end of studies, inadequate methodological strategies, obsolete curricula, etc. There was a consensus regarding the difficulties for young people living in families with low levels of income-and which could thus benefit from another salary-to participate in non-mandatory secondary education. Although educational centres are aware of these reasons, the government generally does not ask about them.

Among the issues regarding educational policies and practices, three stood out: (a) the many difficulties related to evolving the educational offering in accordance with new needs and given the characteristics of the teaching staff; (b) with regard to guidance, insufficient knowledge about VET by part of the teachers and counselling services in the compulsory education system, thus preventing proper student guidance; and (c) the lack of adequate transportation between where students live and the centre that offers the training in which they wish to enrol.

Among the strengths of VET, it was noted that there is an exponential increase in the hiring of students who graduated, one year after they finish their studies. Requests by companies for degree-holding students exceed the number of students who actually hold degrees in a great number of vocations. In order to take advantage of this situation, with respect to the training programmes and job placement for young people, there is a need to increase the social and economic prestige of VET.

The social agreement reached by the participants incorporates a variety of measures that were agreed upon during the social discussion. There was a high level of social awareness 
regarding the seriousness of the problem as well as its systemic and structural nature. This is reflected in the clear focus on measures to prevent dropout, including making fundamental changes to the dynamics of the education system and VET. The proposed changes involve core elements of educational practices, such as curriculum and teacher training, while also encouraging families and the community to participate in finding solutions and points where improvements can be made.

With respect to the curriculum, work focused on motivation and the diversification of contents; examples include the following: coming up with motivating teaching strategies at all stages; working on students' abilities, talents and values throughout the education process; working on different types of competences via experimentation; and building a more flexible and individualized curriculum.

All of those involved in the discussion underscored the need to improve tutoring plans and follow-up throughout the education process, especially when students move from primary to secondary education, in order to detect problems and take specific actions early enough to avoid detachment from the school, which leads to a large number of students dropping out. The consensus regarding the need for measures other than punitive ones (especially expulsion) was unanimous. Among the proposals included in the social agreement, we consider the following to be especially notable: offering students stable tutor figures and stressing emotional bonding using inclusive and cooperative education, focusing on the consideration of ' $\mathrm{I}$ ' and on the centre's education plan as well as spaces and specific hours for providing support to students.

To do this, centres must be properly organized so as to articulate the various measures, defining common objectives and incorporating meetings and shared work into the work schedule. Teachers must also be properly trained. To this point, training regarding the risk factors for dropout and related prevention strategies is a must, as is improving access to basic-level training for teachers using a selection and training process and focusing on teaching attitudes, emotional connections and the development of inclusive education.

Specific measures are paramount to preventing dropout in VET. Among the measures for which a general consensus was reached, we feel that the following five are noteworthy: (1) increasing VET offers, facilitating access to VET programmes and connecting them with the working world; (2) doing away with the division between the VET system, the employment system, etc. by increasing flexibility between existing systems until they can be blended into one; (3) improving and expanding the offers linked to the new constructive model we would like to promote; (4) making VET programmes more flexible and adapting them to the characteristics of the students; and (5) including a rating system for degrees in the job market.

On a more strategic level, the social agreement recognizes increased family and student participation during the various stages of education to be crucial in the fight against dropout (i.e., involving them in the design of the programmes, improving communication channels 
with the education community, etc.). The social agreement proposes making education centres, as well as the various agents in the socio-educational community, more open and permeable so as to promote working in networks and create learning communities.

In line with other participants, it is our belief that for these changes to be carried out, two important issues must be addressed. On the one hand, there should be an autonomous community-level law that covers essential points, such as improving funding, reducing student/teacher ratios and restricting repetition of school years. On the other hand, there must be an autonomous community-level plan to combat early school leaving from VET programmes-and the education system in general-that involves all stakeholders and utilizes the good practices being employed in the formal education system as well as innovative practices coming from third-sector projects.

\section{Discussion and conclusions}

The experience presented herein is part of a greater process of work towards social inclusion and guaranteeing young people a right to education. It was led by the EAPN-IB, whose interests coincide with the main areas of study of the UIB's 'Education and Citizenship' research group: training, work and equity. The social and academic collaboration between these institutions represents a commitment to the exercise of citizenship and the emancipation of individuals and groups as discussed by Lopez-Aranguren (2004) and Carr and Kemmis (1986). We understand that the synergies arising from this type of collaboration give greater legitimacy to the social discussion and greater feasibility to the proposed actions as they stem from an experiment in egalitarian democracy (Subirats, 2012) and contribute to dealing with inequalities from a comprehensive and transformative point of view.

Roundtables, presentations and posters have framed the intense and productive discussion of the group work. The main results of the analysis of the social discussion are the proposals that saw a majority consensus among the participants. As previously noted, the innovation of this exercise in empowered deliberation (Johnson \& Gastil, 2015) lies in equating, at the same level of discussion, researchers, professionals, students and families, administration authorities, third-sector representatives and the politicians in charge of legislation. Of special interest are the intersection of the variety of positions that emerged in the debates as well as the consensus that was reached with regard to the suggested proposals.

Therefore, while the public administration focused on highlighting actions that have been implemented, families, NGOs and professionals underlined the insufficiency of such measures. From a research perspective, we consider that one strategic action would be to deepen the diversity of positions (Keller, 2005, Zenner, 2017), establishing channels for participation and stable debate from which to pilot necessary changes that can combat the problem of ELET, and specifically VET dropout. Stakeholder workshops contribute to existing repre- 
sentative processes (Nielsen, Bryndum \& Bedsted, 2017) and increase community participation in moving policies towards social justice (Walker \& Unterhalter, 2007). This is why we interpret the commitment to maintain this space of shared reflection as a success. Within it, it is remarkable to note the active participation of representatives from each and every parliamentary group in the Balearic Islands.

The contents of the social agreement reflect the consensus reached regarding the need to develop preventative and intervention strategies (Cedefop, 2016), such as working in networks, encouraging collaboration between formal and informal education, the central role of territory and the community and the active participation of students. This consensus is in line with what has been discussed in literature on this topic, notably from the Commission of the European Communities (2004); Moshuus (2018); Puig, Batlle, Bosch and Palos (2007); UNESCO (2015); and Taylor (2010), among others. These proposed actions regarding VET focus on the need to establish a system that integrates vocational education and training from the education system and from the employment system, as well as the need to increase the offer to connect with the needs of businesses, the territory and a new model of production. According to Taylor (2010) and the Cedefop (2016) the need for greater flexibility and attention to student diversity, as well as joint work among education centres and businesses, is key to preventing VET dropout.

The need to improve the quality of the system and move towards more inclusive education was also brought up, as was the need to increase related lines of the budget and offer grants and better transportation in order to enable students to access and remain in VET. Other suggestions included improving public policies related to training teachers to recognize dropout risk factors and prevent them. With regard to teaching practices, of note are the suggestions to give a greater role to students via improving monitoring, follow-up and tutoring; to focus on motivating and diversified contents; and above all, to focus on experiential learning (Kolb, 1984; Kolb \& Kolb, 2005 and 2017).

Each one of the educational agents (formal, informal and non-formal) has its own insecurities stemming from the times of constant change in which we live and which have given way to the so-called 'Penelope syndrome': whatever one educational agent instils into a young person during the day, another agent undoes at night time. Sometimes, one need not even wait until night, as the variability in - often contradictory-educational stimuli can reach extreme levels, as claimed by Del Pozo (2009). In this context, collaborative alliances, such as those described previously, contribute to dealing with this complexity and serve as an opportunity to fight against dropout and favour the right to education. 


\section{References}

Avis, J. (2018). Crossing boundaries Crossing boundaries: VET, the Labour Market and Social Justice. International Journal for Research in Vocational Education and Training (IJRVET), 5(3), $178-190$.

Carr, W. \& Kemmis, S. (1986). Becoming critical: Education, knowledge and action reseach. London: Farmer.

Cedefop (2016). Leaving education early: putting vocational education and training centre stage. Volume I: investigating causes and extent. Publications Office. Cedefop research paper No 57, Luxembourg, Belgium.

Cembranos, F. \& Medina, J. A. (2003). Grupos inteligentes. Teoría y práctica del trabajo en equipo. Madrid, Spain: Editorial Popular.

Commission of the European Communities (2004). Communication from the Commission. The new generation of community education and training programs after 2006. COM (2004) 156 final. Brussels, Belgium. Retrieved from: http://viaa.gov.lv/files/free/48/748/the_new_generation_of_ com_education_2004.pdf

Del Pozo, J. M. (2009). Educació i complexitats. Conferencia pronunciada en la Jornada de reflexió Temps de canvi i complexitat en l'educació.. Consell Escolar de Catalunya. Reus. Retrieved from: http://joanmanueldelpozo.blogspot.com.es/2010/01/educacio-i-complexitats.html

European Antipoverty Network- ES (2015). Seminario de Capacitación al Voluntariado. Estrategia 2020: Una evaluación intermedia de los objetivos sociales desde el Tercer Sector. Retrieved from: https://www.eapn.es/publicaciones/267/estrategia-2020-una-evaluacion-intermedia-de-los-objetivos-sociales-del-tercer-sector

EAPN-IB (2014). Pacte per a la Inclusió Social. Parlament de les Illes Balears, Palma, Spain. Retrieved from: http://xarxainclusio.org/wp-content/uploads/2014/10/inclusiosocial.pdf

Geissel, B. \& Hess, P. (2017). Explaining Political Efficacy in Deliberative Procedures - A Novel Methodological Approach. Journal of Public Deliberation, 13(2). Retrieved from: https://www.publicdeliberation.net/jpd/vol13/iss2/art4

Johnson, C. \& Gastil, J. (2015). Variations of Institutional Design for Empowered Deliberation. Journal of Public Deliberation, 11(1),. Retrieved from: https://www.publicdeliberation. net/jpd/vol11/iss1/art2

Institute of Education Sciences (2017). Preventing dropout in secondary schools. Educator's practice guide. A set of recommendations to address challenges in classrooms and schools. US Department of Education. Retrieved from: https://ies.ed.gov/ncee/wwc/Docs/PracticeGuide/wwc_dropout_092617.pdf

Keller, R. (2005). Analyzing Discourse. An Approach From the Sociology of Knowledge. FQS. Forum: Qualitative Social Research, 6(3). Retrieved from: http://www.qualitative-research.net/index.php/ fqs/article/view/19/41

Kolb, D. (1984). Experiential learning. Experience as the source of learning and sevelopment. New Jersey, USA: Prentice Hall.

Kolb, D. A., \& Kolb, A. Y. (2005). Learning styles and learning spaces: enhancing experiential learning in higher education. Academy of Management Learning \& Education, 4(2), 193-212. doi:10.5465/ AMLE.2005.17268566 
Kolb, D. A., \& Kolb, A. Y. (2017). Experiential learning theory as a guide for experiential educators in higher education. ELTHE: A Journal for Engaged Educators, 1(1), 7-44. Retrieved from: https:/learningfromexperience.com/downloads/research-library/experiential-learning-theoryguide-for-higher-education-educators.pdf

Llano, J.C. (2017). $6^{\circ}$ Informe 2016. El estado de la pobreza. Seguimiento del Indicador de Riesgo de Pobreza y Exclusión Social en España 2009-2015. EAPN. European Antipoverty Network. Retrieved from: http://www.eapn.es/estadodepobreza/ARCHIVO/documentos/Informe_AROPE_2016. pdf

López-Aranguren, L. (2004). Perspectivas para la formación y empleo para las personas en situación de exclusión. Documentación Social, 135, 35-55. Retrieved from: https://www.caritas.es/producto/ intervencion-ante-la-exclusion-social/

López-Aranguren, L. (2007). ¿Por qué hacemos lo que hacemos? Una propuesta de debate para el Tercer Sector. Madrid, Spain: Fundación Tomillo.

Ministerio de Educación, Cultura y Deporte (2017). Sistema estatal de indicadores de la educación 2017. Retrieved from: https://www.mecd.gob.es/inee/indicadores/sistema-estatal/edicion-2017. html

Ministerio de Educación, Cultura y Deporte (2017). Indicadores de la Educación de la Estrategia Europea 2020. Retrieved from: https://www.educacion.gob.es/educabase/menu.do? type $=$ pcaxis\&path $=/$ Formacionyml/EPA2015/Indi\&file=pcaxis\&l=s0

Moshuus, G. (2018) De vuelta al centro escolar: un baile sobre la cuerda floja. Presentation at the social discussion. Reduir labandonament primerenc de leducació i la formació a les Illes Balears: cap an un consens necessari. Jornades 8 i 9 de febrer de 2018. Parlament de les Illes Balears, Palma. Retrieved from: https://docs.wixstatic.com/ugd/e8be71_2ed5f3884add4ae3893fc128990ec716.pdf

Nielsen, M.V., Bryndum, N. \& Bedsted, B. (2017). Organising stakeholder workshops in research and innovation between theory and practice. Journal of Public Deliberation, 13(2).

Retrieved from: https://www.publicdeliberation.net/jpd/vol13/iss2/art9

OECD (2017). The OECD Handbook for innovative learning environments. OECD Publishing, Paris, France. Retrieved from: http://dx.doi.org/9789264277274-en

Plataforma de ONGs de Acción Social (2015). El tercer sector de acción social en 2015: impacto de la crisis. POAS, Madrid, Spain. Retrieved from: http://www.plataformaong.org/ciudadaniaactiva/ tercersector/estudio_completo_el_TSAS_en_2015_impacto_de_la_crisis.pdf

Puig, J.M., Batlle, R., Bosch, C. \& Palos, J. (2007). Aprendizaje y servicio (ApS). Educación y compromiso cívico. Barcelona, Spain: Graó.

Salvà-Mut, F. (2017). Formació i competències del capital humà de les Illes Balears. En Conselleria de Treball, Comerç i Indústria (Ed.). Anuari del Treball de les Illes Balears 2016 (pp.169-184).

Govern de les Illes Balears, Palma, Spain.

Salvà-Mut, F. (2018). Abandonament i retorn als estudis en un marc de 'postcrisi' i revisió de model turístic. Reduir labandonament primerenc de leducació i la formació a les Illes Balears: cap a un consens necessari. Jornades 8 i 9 de febrer de 2018. Parlament de les Illes Balears, Palma, Spain. Retrieved from: https://docs.wixstatic.com/ugd/e8be71_ee684787bd9e40a6893f4c26cf4f314f.pdf

Salvà-Mut, F, Oliver-Trobat, M. \& Calvo-Sastre, A. (2006). Young people of low educational level: Promoting innovative projects. European Journal of vocational training, 38(2), 49-65. 
Salvà-Mut, F, Oliver-Trobat, M.F. \& Comas-Forgas, R. (2014). Abandono escolar y desvinculación de la escuela: perspectiva del alumnado. Magis, Revista Internacional de Investigación en Educación, 6(13), 129-142.

Salvà-Mut, F., Oliver-Trobat, M.F., Ruiz-Pérez, M. \& Psifidou, I. (2020). Formación profesional de grado medio y abandono temprano de la educación y la formación en España: una aproximación territorial. Revista de Investigación Educativa. (Under review).

Salvà-Mut, F; Quintana-Murci, E. \& Desmarais, D. (2015). Inclusion and exclusion factors in adult education of youth with a low educational level in Spain. European Journal of Research on the Education and Learning of Adults, 6(1), 9-23.

Salvà-Mut, F., Thomás-Vanrell, C. \& Quintana-Murci, E. (2016). School-to-work transitions in times of crisis: the case of Spanish youth without qualifications. Journal of Youth Studies, 19(5), 593-611.

Subirats, J. (2012). ¿Qué democracia tenemos? ¿Qué democracia queremos? Anales de la Cátedra Francisco Suárez, 46 (2012), 155-180. Retrieved from: https://dialnet.unirioja.es/servlet/ articulo? codigo $=4254304 \#$ ?

Taylor, A. (2010). Challenging transitions from school to work. In D.W. Livingstone, (Ed.), Lifelong Learning in Paid and Unpaid Work. Survey and case study findings, (pp. 175-192). London, UK: Routledge.

Unesco (2015). Rethinking education. Towards a global common good? Unesco, Paris, France. Retrieved from: http://unesdoc.unesco.org/images/0023/002325/232555e.pdf

Unicef-Comité Baleares (2017). La infancia en las Illes Balears. 'Rumbo a la aplicación de la agenda 2030'. Unicef-Comité Baleares, Palma, Spain. Retrieved from: https://www.unicef.es/publicaciones/la-infancia-en-las-illes-balears-2017

Unicef (2017). Los factores de la exclusión educativa en España: Mecanismos, perfiles y espacios de intervención. Unicef, Madrid, Spain. Retrieved from: https://www.unicef.es/publicacion/los-factores-de-la-exclusion-educativa-en-espana

Walker M. \& Unterhalter E. (Eds.) (2007). Amartya Sen's Capability Approach and Social Justice in Education. New York, USA: Palgrave Macmillan.

Zenner, L. (2017). 'The lamentation about the bad school leaver' in Germany and England: An analysis of the current and historical discourse among main players involved in VET. In F. Kaiser \& S. Krugmann (Ed.), Social dimension and participation in vocational education and training. Proceedings of the 2nd conference 'Crossing boundaries in VET' (pp. 214-218). University of Rostock, Germany. 


\section{Bibliographical notes}

Dr Francesca Salvà is an associate professor at the Department of Applied Pedagogy and Educational Psychology and member of the research group 'Education at Citizenship' (http:// eic.uib.eu) at the University of the Balearic Islands, Spain. Her research interests focus on vocational education and training, school dropout, training and career paths, young people with low education profiles, gender, work and education.

Dr Carme Pinya is an assistant professor at the at the Department of Applied Pedagogy and Educational Psychology and member of the research group 'Childhood, Technology, Education and Diversity (GITED).' She is currently working on teacher education, inclusive education, teaching methods and educational innovation.

Dr Nuria Álvarez is member of the research group 'Education at Citizenship' (http://eic.uib. eu) at the University of the Balearic Islands, Spain. Her research interests focus on the construction of otherness, racism, ethnocentrism, prejudice and stereotype.

Dr Aina Calvo is an associate professor at the Department of Applied Pedagogy and Educational Psychology and member of the research group 'Education at Citizenship' (http://eic. uib.eu) at the University of the Balearic Islands, Spain. Her research interests focus on community development, social participation and youth work. 